\title{
Evaluation of the Bioavailability and Pollution Indexes of Some Toxic Metals in Polluted Soils from an Abandoned Mining Area
}

\author{
CRISTINA DINU1,2, ELEONORA MIHAELA UNGUREANU², GABRIELA GEANINA VASILE*, LIDIA KIM¹, \\ LUOANA FLORENTINA PASCU ${ }^{1}$, MARIUS SIMION ${ }^{1}$ \\ ${ }^{1}$ National Research and Development Institute for Industrial Ecology ECOIND Bucharest, 71-73 Drumul Podul Dambovitei Str., \\ 060652, Bucharest, Romania \\ 2University Politehnica of Bucharest, Faculty of Applied Chemistry and Materials Science, 1-7 Polizu Str., 011061, Bucharest, \\ Romania \\ The paper presents soil quality assessment using pollution and bioavailability indexes in order to highlight \\ possible pollution generated by a decommissioned mining area in Certej, Deva County, Romania. Metals \\ such as $\mathrm{Cd}, \mathrm{Cr}, \mathrm{Cu}, \mathrm{Ni}, \mathrm{Pb}$ and $\mathrm{Zn}$ were analyzed in pseudo-total and mobile form and the results were \\ correlated with the content found in the vegetation collected from the same points during a previous study. \\ The research shows a high mobility for $\mathrm{Ni}, \mathrm{Pb}$ and $\mathrm{Zn}$, respectively, a moderate mobility for $\mathrm{Cd}$.
}

Keywords: bioavailability index, metals, mining site, pollution indexes, soil

Soil is a non-regenerative resource that fulfills several vital functions including: food/biomass production; storage, filtration and conversion of certain substances; is a source of biodiversity, habitats, species and genes; serves as a platform/physical environment for people and human activities; is a source of raw materials; is a geological and archaeological heritage etc. Among the forms of soil pollution, the most serious is the pollution of the soil by its destruction on large surfaces due to pollution from mining and industrial exploitations [1].

Soil $\mathrm{pH}$ can be highlighted as an important characteristic. Nutrients and pollutants mobility (availability) is directly dependent on the $\mathrm{pH}$ value [2]. The activity of soil organisms, the degradation of organic substances, the release of iron, manganese and aluminum also depend on $\mathrm{pH}$ level. The solubility of metals increases at low $\mathrm{pH}$ and decreases at high $\mathrm{pH}$ [3]. It is known that metals adsorption is directly proportional to the soil $\mathrm{pH}$, this fact being observed in many adsorbent components of the soil as well as in different soil types [4]. The effects that pH generates on soil solubility can also be observed in precipitation-dissolution reactions. Acid rains have a $\mathrm{pH}$ of less than 5.6, this pH being due to inorganic (sulfuric, nitric) and organic (formic, acetic, carbonic) acids resulting from complex atmospheric reactions [5].

Soils from industrialized and urban areas accumulate metallic trace elements, affecting the ecosystems and the human health [6-8] and posing serious risks to biota. Many researches pointed out that mining activity can be considered a main source of heavy metals contamination of vicinity soils and sediments [7].

Classically, soil pollution risk evaluations focus on total trace metal concentrations, but trace metal bioavailability based on their physical chemical fractions seem to be more relevant, providing a more accurate estimate of the environmental impact [4].

Evaluation of the bioavailability processes in soils and sediments should use different methods, including besides usual measurements of total content - the calculation of specific indexes as tools for risk assessment [6].

Assessing soil contamination levels of heavy metals by applying different techniques may result in discrepancies, thus it is important to compare results obtained using different relevant factors and indexes such as contamination factor [7], enrichment factor [9], pollution, bioavailability and geoaccumulation indexes [9] or to sum different individual risks in order to estimate the total pollution risk [10].

The paper presents the assessment of soil quality in a polluted mining area located in Deva County, Romania, using pollution indexes. In this area, a complex study was carried out, which aimed to assess the quality of all environmental factors, namely surface water and sediment [11], soil, vegetation [12].

\section{Experimental part}

Sample collection and preparation

Soil samples were taken from the Certej Basin (Hunedoara County). Soil samples (10 samples and a control sample) were collected, each on 2 depths (0-10 $\mathrm{cm}$ and 30-40 cm), from 11 harvest points.

The blank sample was selected at a distance of about 5 $\mathrm{km}$ in the direction of SV of Coranda quarry, being located in a sufficiently remote area, considered unpolluted die to the mining activity carried out for decades in the selected area.

The location of harvesting points is shown in Figure 1, while GPS coordinates and sample indices are shown in Table 1. Soil samples were collected from sensitive use areas, vegetated soils situated outside the area that was used in mining activities. Soil samples were collected according to the standards in force [13]. Sampling was performed with the Buerkle soil sampling device.

\section{Analytical procedures}

Pseudo-total metal content

For the determination of the pseudo-total content $(\mathrm{Cd}$, $\mathrm{Cr}, \mathrm{Cu}, \mathrm{Fe}, \mathrm{Ni}, \mathrm{Pb}, \mathrm{Zn}$ ), the soil samples were air-dried, milled, sieved and homogenized, retaining the fraction of less than $150 \mu \mathrm{m}$ for analysis. About $2 \mathrm{~g}$ of soil were weighed in Berzelius beakers, a mixture of $7 \mathrm{~mL} \mathrm{HNO}_{3}$ and $21 \mathrm{~mL} \mathrm{HCl}$ was added and it was mineralized in open system until the remaining liquid had cleared. The mixture was filtered, washed with distilled water and the obtained filtrate was collected in a $50 \mathrm{~mL}$ volumetric flask [14]. The solution thus obtained was used for the determination of metals by

\footnotetext{
* email: gabriela.vasile@incdecoind.ro
} 


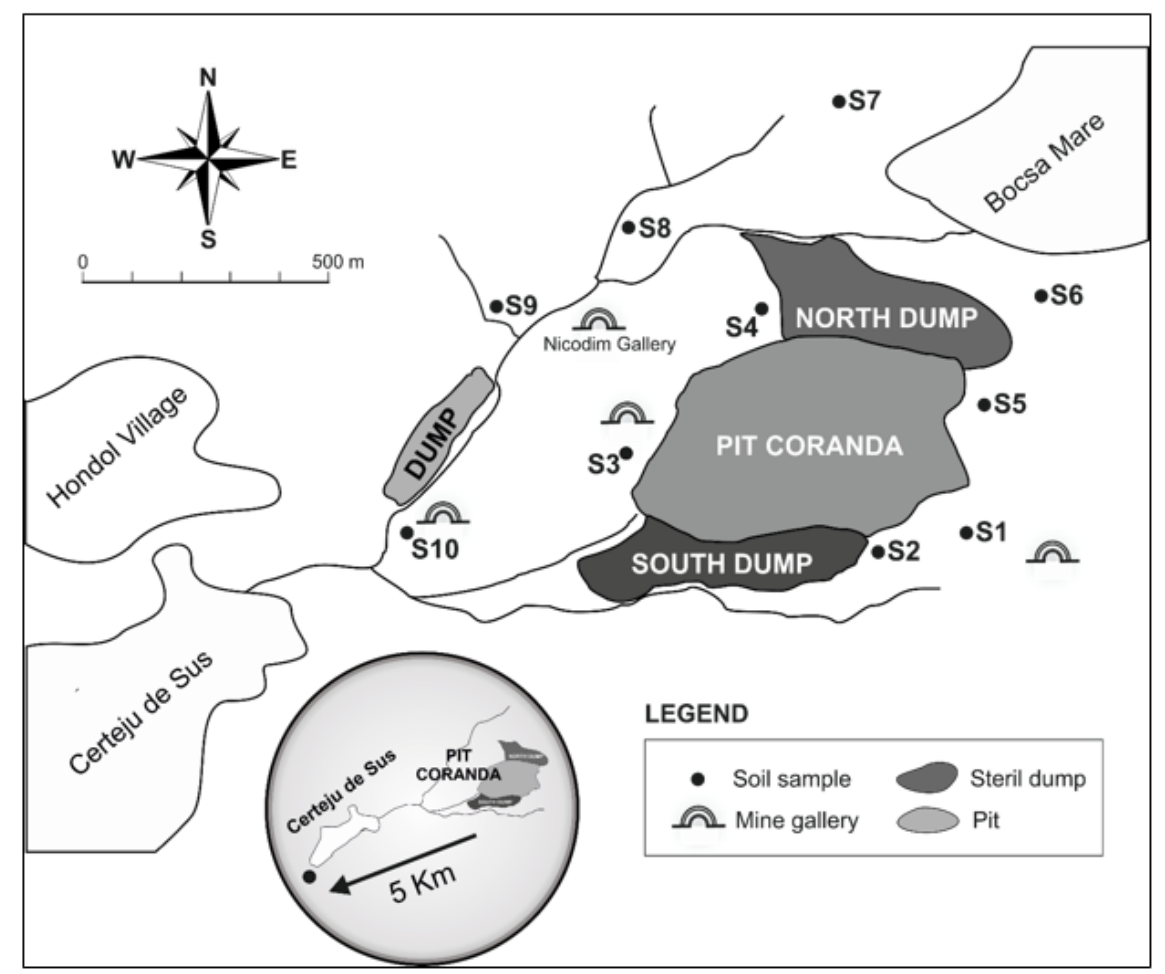

Fig. 1. Map of soil sampling points, Certej Area

Table 1

GPS COORDINATES OF SOIL SAMPLING POINTS

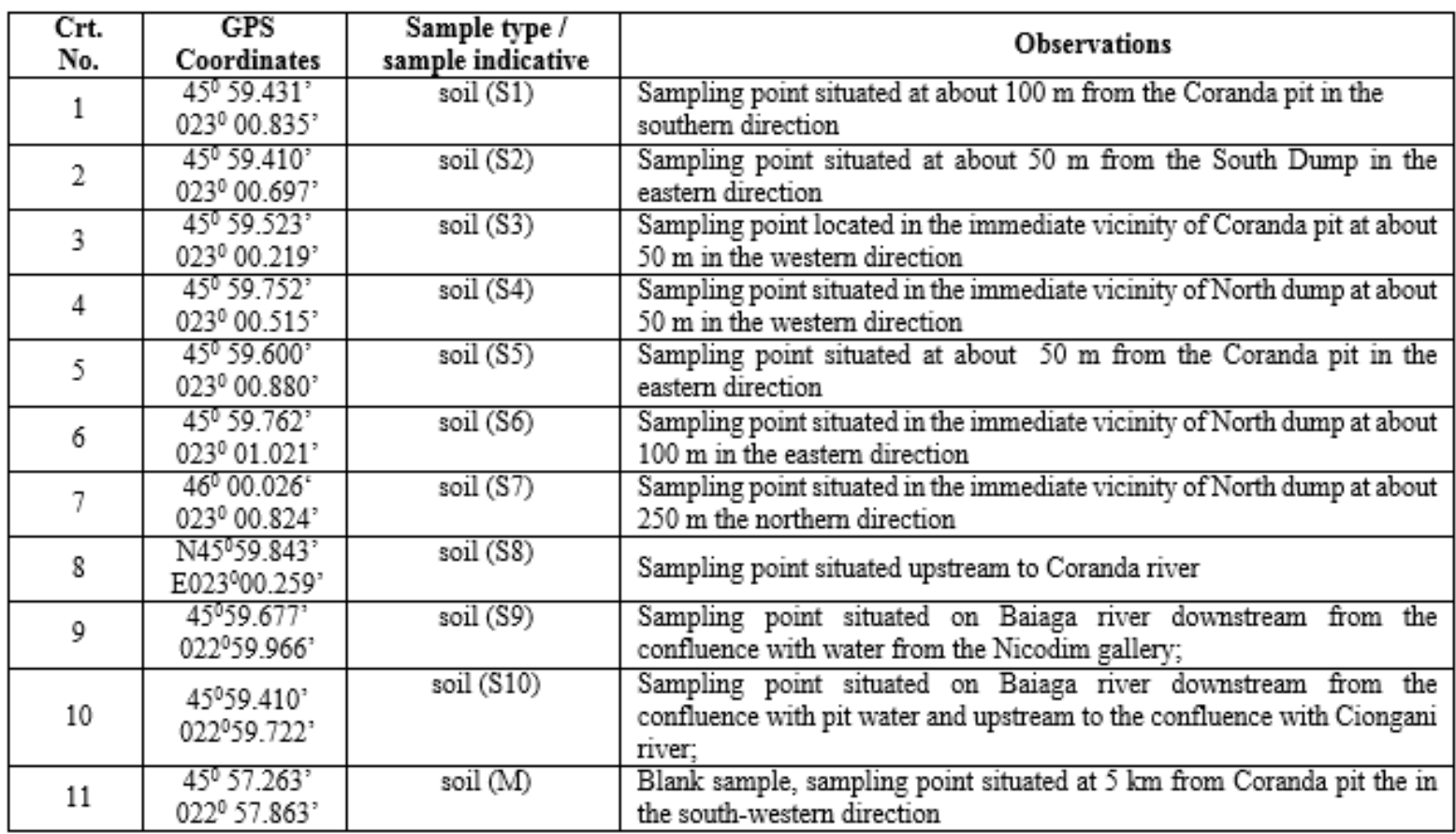

inductively coupled plasma optical emission spectrometry on an Optima 5300 DV Perkin Elmer equipment.

\section{Mobile fraction}

For mobility tests, three simple chemical extraction methods were used, using different chemical reagents and soil-to-extractant ratios. Both weak extractants (e.g. $\mathrm{CH}_{3} \mathrm{COONH}{ }_{4}, \mathrm{NH}_{4} \mathrm{NO}_{3}$ ) and strong complexing agents (chelating agents), such as EDTA, or a mixture of them $[15,6]$ were used:

Method I: NF X 31 - 120/2003 Standard: 0.01 M EDTA + $1 \mathrm{M} \mathrm{CH}_{3} \mathrm{COONH}_{4}, \mathrm{pH}=7 \pm 0.002$, soil/extraction solution ratio $=1: 10$, stirring time: $2 \mathrm{~h}$ at 40 rotations/min; [16].

Method II: ISO 19730:2008 Standard : $1 \mathrm{M} \mathrm{NH}_{4} \mathrm{NO}_{3}, \mathrm{pH}$ $7 \pm 0.002$, soil/extraction solution ratio $=1: 2.5$, stirring time: $2 \mathrm{~h}$ at 40 rotations/min; [17].
Method III: ONORM L 1094-2/2016 Standard: $\mathrm{CH}_{3} \mathrm{COONH}_{4}, \mathrm{pH}=7 \pm 0.002$, soil/extraction solution ratio $=1: 10$, stirring time: $2 \mathrm{~h}$ at 40 rotations/min; [18].

Pre-treated soil samples were used according to ISO 11464 [14], following the same procedure as for the pseudo-total content. From each sample, a sub-sample (5 g) was weighed and transferred into a $100 \mathrm{~mL}$ iodine flask. A separate part of these samples was used to determine the water content. $50 \mathrm{~mL}$ of extraction solution (method I and III), respectively $12.5 \mathrm{~mL}$ (method II) was added. The containers were sealed and shaken for $2 \mathrm{~h}\left(20 \pm 2^{\circ} \mathrm{C}\right)$ using a shaker. The extracts were decanted into centrifuge vials and centrifuged for $10 \mathrm{~min}$ at $3000 \mathrm{rpm}$. The supernatant obtained from each sample was filtered using a membrane filter with a porosity of $0.45 \mu \mathrm{m}$.

The content of $\mathrm{Cd}, \mathrm{Cr}, \mathrm{Cu}, \mathrm{Ni}, \mathrm{Pb}, \mathrm{Zn}$ was determined using inductively coupled plasma optical emission spectrometry. 
Estimation of pollution index and bioavailability index

Interpretation of the obtained analytical results was achieved both by reference to the indicators' values for the reference samples (control samples) and by reference to the limits stipulated in the MAPPM Order No. nr. 756/ 1997- Regulations on environmental pollution assessment which introduces the notions of normal value, alert value (PA) and intervention value (PI).

As reported in literature, numerous factors / indexes can be used in order to estimate soil quality $[9,19,7]$. Pollution index for the soil can be quantified in terms of contamination factor $\left(C_{f}\right)$, calculated as the ratio of average metal concentration in the soil samples to the baseline reference concentration in the earth crust [20], as summarised in the following formula [21].

$$
C_{f}=\frac{c_{i}}{c_{e}}
$$

where, $C_{i}$ represent the mean concentration of the metal in the examined samples, respectively $C_{e}$ - the normal value of the metal in the earth crust.

As for the interpretation of contamination factor values, higher value indicate lower retention time of the element in the soil and thus a higher risk to the environment [22].

The degree of contamination, $C_{d}$, which is an overall indicator of contamination, is estimated by summing the contamination factors $\left(C_{f}\right)$ of each pollutant.

$$
C_{d}=\sum_{i=1}^{n} C f
$$

where $n$ is the number of analyzed elements, irepresents the pollutant, while $C_{f}$ signifies the contamination factor.

$\mathrm{C}_{d}$ is determined also as the ratio of metal concentration in soil to the metal's background values.

The modified degree of contamination $\left(\mathrm{mC}_{d}\right)$ is calculated as the sum of all the contamination factors divided by the number of analyzed pollutants. This index averages the contamination of all elements at a particular site through a single value and is determined using the following formula [10]:

$$
m C_{d}=\frac{\sum_{i=1}^{n} c f}{n}
$$

The level of contamination using the $C_{d}$ index is shown in table 2.

Table 2

MODIFIED DEGREE OF CONTAMINATION AND ITS EFFECTS

\begin{tabular}{|c|l|}
\hline $\mathrm{mC}_{\mathrm{d}}$ levels & \multicolumn{1}{|c|}{ Contamination status } \\
\hline $\mathrm{mC}_{\mathrm{d}}<1.5$ & Very low degree of contamination \\
\hline $1.5 \leq \mathrm{mC}_{\mathrm{d}}<2$ & Low degree of contamination \\
\hline $2 \leq \mathrm{mC}_{\mathrm{d}}<4$ & Moderate degree of contamination \\
\hline $4 \leq \mathrm{mC}_{\mathrm{d}}<8$ & High degree of contamination \\
\hline $8 \leq \mathrm{mC}_{\mathrm{d}}<16$ & Very high degree of contamination \\
\hline $16 \leq \mathrm{mC}_{\mathrm{d}}<32$ & Extremely high degree of contamination \\
\hline $\mathrm{mC}_{\mathrm{d}} \geq 32$ & Ultra high degree of contamination \\
\hline
\end{tabular}

Another relevant index is the Geoaccumulation index $\left(I_{\text {aep }}\right)$, which compares the current concentration in the soll with the pre-industrial pollution, being defined by the mathematical relation:

$$
I_{g e o}=\log _{2}\left(C_{n} / 1.5 B_{n}\right)
$$

where $C_{n}$ is the metal concentration, while $B_{n}$ represents the background of the element [17]. 3.

$I_{\text {geo }}$ is classified into seven classes [7] as shown in Table

To evaluate the soil contamination rate, Enrichment Factor (EF) can be also applied. Enrichment factor can be

\begin{tabular}{|c|c|c|}
\hline$I_{g e 0}$ & Class & Soil quality \\
\hline $\mathrm{I}_{g 00} \leq 0$ & 1 & Practically unpolluted \\
\hline $0<I_{g 00}<1$ & 2 & Unpolluted to moderately polluted \\
\hline $1<I_{g 00}<2$ & 3 & Moderately polluted \\
\hline $2<I_{g 00}<3$ & 4 & Moderately to strongly \\
\hline $3<I_{g 00}<4$ & 5 & Strongly polluted \\
\hline $4<I_{g 00}<5$ & 6 & Strongly to very strong \\
\hline $5<I_{g} \approx 0$ & 7 & Very strong pollution \\
\hline
\end{tabular}
evaluated considering the differences between the natural
Table 3

THE CLASSES OF THE VALUE OF I

and the anthropogenic contribution of the metals in soil [8], according to the next formula:

$$
E F=\left\lfloor\frac{X}{F e}\right\rfloor_{\text {sample }} /\left\lfloor\frac{X}{F e}\right\rfloor_{\text {crust }}
$$

where $\left\lfloor\frac{X}{F e}\right\rfloor_{\text {sample }}$ and $\left\lfloor\frac{x}{F e}\right\rfloor_{\text {crust }}$ represent the ratio of average concentrations of the target metal and Fe in the studied sample and earth crust, respectively.

In this case Fe is used as a reference element. The most common reference elements are $\mathrm{Sc}, \mathrm{Mn}, \mathrm{Al}$ and $\mathrm{Fe}$.

$E F$ is classified in five contamination categories, as appears in table 4.

Table 4

THE CLASSES OF THE VALUE OF EF

\begin{tabular}{|c|l|}
\hline $\mathrm{EF}<2$ & Depletion to minimal enrichment \\
\hline $2<\mathrm{EF}<5$ & Moderate enrichment \\
\hline $5<\mathrm{EF}<20$ & Significant enrichment \\
\hline $20<\mathrm{EF}<40$ & Very high enrichment \\
\hline $\mathrm{EF}>40$ & Extremely high enrichment \\
\hline
\end{tabular}

The ability to transfer metals from the soil to the environment is estimated by calculating the Index of Bioavailability $\left(\mathrm{I}_{\text {bio }}\right)$ using the following formula:

$$
I_{\text {bio }}(\%)=\frac{\text { Cmobil } * 100}{\text { Ctotal }}
$$

where $\mathrm{C}_{\text {mobil }}$ is the content of metal from exchangeable form, water soluble and weak acid soluble fraction (carbonates), while $C_{\text {rat }}$ represents the total concentration of metal in the soil sample.

\section{Results and discussions}

\section{Distribution of the metals}

Table 5 lists the minimum, maximum, average, and median values for the pseudo-total and mobile metal content of the 20 samples, collected from 10 sampling points, 2 depths.

The pseudo-total content is used in the evaluation of different pollution indexes ( $E F, C_{f,} m C d, I_{\text {geo }}$ ), highlighting the degree of pollution within the studied area, contaminated by past mining activities. Even if the area was shut down for mining activities, the pollution generated in the past continues to rise environmental concerns. The tabulated data show that there are exceedances of intervention limits for $\mathrm{Cd}, \mathrm{Cu}, \mathrm{Ni}, \mathrm{Pb}$ and $\mathrm{Zn}$, the recorded exceedances being 2.3 times higher in the case of $\mathrm{Cd} ; 1.9$ times higher for $\mathrm{Cu}$; 4 times higher for $\mathrm{Ni} ; 8.9$ times higher for $\mathrm{Pb}, 3.7$ times higher for $\mathrm{Zn}$.

The values of the mobile fraction obtained by applying the three extraction methods were reported. By comparing the results, it can be observed that methods using ammonium acetate in a mixture with EDTA (method I) or ammonium acetate only (method III) extract high amounts of metals into the mobile form. By comparing the bioavailability indexes $\left(I_{\text {bio }}\right)$ evaluated for each metal and 


\begin{tabular}{|c|c|c|c|c|c|c|c|}
\hline & & $\mathrm{Cd}$ & $\mathrm{Cr}$ & $\mathrm{Cu}$ & $\mathrm{Ni}$ & $\mathrm{Pb}$ & $\mathrm{Zn}$ \\
\hline & Min & 0.05 & 3.95 & 9.45 & 2.2 & 13.4 & 56.3 \\
\hline \multirow[t]{3}{*}{ Total } & $\operatorname{Max}$ & 11.4 & 73.6 & 378 & 610 & 888 & 2202 \\
\hline & Mean & 1.25 & 27.2 & 61.9 & 84.6 & 224 & 369 \\
\hline & Median & 2.27 & 22.6 & 25.8 & 23.8 & 133 & 182 \\
\hline \multirow[t]{4}{*}{$\begin{array}{l}\text { Exch: } \\
\text { Meth }\end{array}$} & Min & 0,05 & 0.08 & 1.87 & 0.62 & 2.67 & 26.3 \\
\hline & $\operatorname{Max}$ & 8.16 & 16.5 & 264 & 180 & 193 & 1309 \\
\hline & Mean & 1.24 & 5.82 & 36.9 & 28.3 & 49.1 & 198 \\
\hline & Median & 0.73 & 7.14 & 12.5 & 12.6 & 23.3 & 84.7 \\
\hline \multirow[t]{4}{*}{$\begin{array}{l}\text { Excha } \\
\text { Methe }\end{array}$} & Min & 0,05 & 0.05 & 0.08 & 0.07 & 0.01 & 10.3 \\
\hline & $\operatorname{Max}$ & 3.02 & 2.13 & 87.6 & 153 & 29.4 & 781 \\
\hline & Mean & 0.48 & 0.30 & 8.74 & 18.5 & 3.19 & 101 \\
\hline & Median & 0.14 & 0.06 & 0.73 & 7.2 & 0.68 & 24.7 \\
\hline \multirow[t]{4}{*}{$\begin{array}{l}\text { Excha } \\
\text { Methe }\end{array}$} & Min & 0,05 & 0.33 & 1.04 & 0.11 & 3.64 & 16.3 \\
\hline & $\operatorname{Max}$ & 7.20 & 11.6 & 164 & 126 & 209 & 1323 \\
\hline & Mean & 1.00 & 5.82 & 18.3 & 18.4 & 43.9 & 154 \\
\hline & Median & 0.57 & 7.69 & 4.92 & 7.99 & 20.5 & 42.8 \\
\hline Normal value & & 1 & 30 & 20 & 20 & 20 & 100 \\
\hline Alert value (PA) & & 3 & 100 & 100 & 75 & 50 & 300 \\
\hline $\begin{array}{l}\text { Intervention } \\
\text { value }(\mathrm{PI})\end{array}$ & & 5 & 300 & 200 & 150 & 100 & 600 \\
\hline
\end{tabular}

Table 5

STATISTICAL DISTRIBUTION OF PARAMETERS FOR SELECTED METALS $(\mathrm{mg} / \mathrm{kg})$ iN BOTH FRACTIONS OF ALL SOIL SAMPLES, PSEUDOTOTAL AND MOBILE CONTENT method, Method I was selected as the optimal single chemical extraction method for the investigated soil.

\section{Evaluation of soil quality using pollution indexes}

Modified degree of contamination index

The contamination factor has been calculated in two ways, either by reference to the terrestrial crust reference value $C_{f} c[20]$ or by reference to the normal soil value according to the Romanian legislation in force [23], $C_{f} n$.

Overall degree of contamination $\left(C_{d}\right)$, which sums the individual factors of contamination, has a value of 24.4 when the normal soil value is used as reference value [23], respectively a value of 31.9 when the normal value in earth crust is used as the reference value [20].
In terms of modified degree of contamination index [10], both approaches indicates a high degree of contamination of the analyzed soils $\left(4 \leq \mathrm{mC}_{d} \leq 8\right)$.

Enrichment factor

During the calculation of the enrichment factor, reference values in the terrestrial crust were used [20], the normalization being based on the iron content. Factors for all collected samples were calculated, as well as the average value for each element and the standard deviation. Table 8 lists the enrichment factors ( minimum, maximum and average values; standard deviation).

\begin{tabular}{|c|c|c|c|c|c|c|}
\hline & $\mathrm{Cd}$ & $\mathrm{Cr}$ & $\mathrm{Cu}$ & $\mathrm{Ni}$ & $\mathrm{Pb}$ & $\mathrm{Zn}$ \\
\hline $\mathrm{Ci}$ & 1.25 & 27.2 & 61.9 & 84.6 & 224 & 369 \\
\hline $\mathrm{Cn}^{*}$ & 1.00 & 30.0 & 20.0 & 20.0 & 20.0 & 100 \\
\hline $\mathrm{C}_{f} \mathrm{n}$ & 1.25 & 0.91 & 3.10 & 4.23 & 11.2 & 3.69 \\
\hline$C_{d}=\Sigma C_{f} n$ & \multicolumn{2}{|c|}{24.4} & \multicolumn{2}{|c|}{$\mathrm{mC}_{\mathrm{d}}=\mathrm{C}_{\mathrm{s}} / 6$} & \multicolumn{2}{|c|}{4.06} \\
\hline
\end{tabular}

Table 6

CONTAMINATION FACTOR USING PSEUDOTOTAL CONTENT REPORTED TO THE NORMAL VALUES OF METAL IN SOIL

\begin{tabular}{|l|c|c|c|c|c|c|}
\hline & $\mathbf{C d}$ & $\mathbf{C r}$ & $\mathbf{C u}$ & $\mathbf{N i}$ & $\mathbf{P b}$ & $\mathbf{Z n}$ \\
\hline $\mathrm{Ci}$ & 1.25 & 27.2 & 61.9 & 84.6 & 224 & 369 \\
\hline $\mathrm{Cn}_{\text {crust }}$ & 0.15 & 102 & 60.0 & 84.0 & 14.0 & 70.0 \\
\hline $\mathrm{C}_{f} \mathrm{C}$ & $\mathbf{8 . 3 3}$ & 0.27 & 1.03 & 1.01 & $\mathbf{1 6 . 0}$ & 5.27 \\
\hline $\mathrm{C}_{\mathrm{d}}=\Sigma \mathrm{C}_{f} \mathrm{c}$ & $\mathbf{3 1 . 9}$ & & $\mathrm{mC}_{\mathrm{d}}=\mathrm{C}_{d} / 6$ & $\mathbf{5 . 3 2}$ & \\
\hline
\end{tabular}

Cn crust ${ }^{*}[20]$

\begin{tabular}{|c|c|c|c|c|c|c|c|}
\hline \multirow{5}{*}{$\mathrm{EF}$} & & $\mathrm{Cd}$ & $\mathrm{Cr}$ & $\mathrm{Cu}$ & $\mathrm{Ni}$ & $\mathrm{Pb}$ & $\mathrm{Zn}$ \\
\hline & Min & 1.37 & 0.16 & 0.65 & 0.18 & 3.93 & 3.37 \\
\hline & $\operatorname{Max}$ & 182 & 1.86 & 15.1 & 19.0 & 163 & 75.6 \\
\hline & Mean & 47.8 & 0.88 & 2.98 & 2.90 & 55.9 & 15.6 \\
\hline & SD & 45.6 & 0.57 & 3.86 & 5.51 & 58.3 & 19.4 \\
\hline
\end{tabular}

The highest values of $\mathrm{EF}$ were recorded for $\mathrm{Cd}$ and $\mathrm{Pb}$.
Table 7

CONTAMINATION FACTOR USING PSEUDO-TOTAL CONTENT REPORTED TO REFERENCE VALUES OF METAL IN TERRESTRIAL CRUST

Table 8

STATISTICAL DATA FOR ENRICHMENT FACTOR (EF) 
Regarding the $\mathrm{Cd}$ content, $45 \%$ of the samples fall in the extremely high enrichment range (EF> 40), 30\% being included in the very high enrichmentrange $(20<\mathrm{EF}<40)$, while the average value of all factors is higher than the maximum value of 40 . Very high values of EF indexes were found in soils S2, S3, S4, S5 and S10. The highest value was recorded in S10 sample (first level), where EF is 182.

For $\mathrm{Pb}, 40 \%$ of the samples are in the extremely high enrichment range, with $20 \%$ being in the moderate, significant to very high enrichment ranges. Samples that have high EF values are S2, S3, S5 and S10. In the case of $\mathrm{Pb}$, the mean EF value for all soil samples is higher than the maximum value of 40 , corresponding to an extremely high enrichment (55.9). The highest values were determined in S3, respectively S5 soil samples (values higher than 150).

As regards chromium, all EF values are below 2, indicating depletion to minimal enrichment.

For copper, S10 soil samples (both levels) show significant enrichment, while S1, S2 and S3 soil samples show moderate enrichment, the average EF value on all analyzed samples ranging from 2 to 5 .

Regarding the $\mathrm{Ni}$ content, the S3 sample indicates significant enrichment (10\%), while only $20 \%$ of the samples (S2, S7, S10) were in the moderate enrichment range, with insignificant contribution of the rest of the samples.

For the zinc content, 10\% show extremely high enrichment (S10 samples), 10\% very high enrichment(S3 samples), and most samples (50\%) being classified as significant enrichment. Also, the average value of these samples is very close to the upper threshold of the significantenrichment range. The highest values in the S10 sample are above the value of the $\mathrm{EF}$ index (64).

Overall, samples showing enrichment indexes falling in the extremely high enrichment range are $\mathrm{S} 2(\mathrm{Cd}, \mathrm{Pb}), \mathrm{S} 3$ $(\mathrm{Cd}, \mathrm{Pb})$, S4 (Cd), S5 (Cd, Pb), S10 (Cd, Pb, Zn) samples.

\section{Geoaccumulation index}

When evaluating the geoaccumulation index, the normal value in soil according to the Romanian legislation in force was taken as the reference value (table 5) and the pseudototal metal concentrations were used. Similar reports for $I_{\text {geo }}$ calculations were recorded in the soils collected from an area adjacent to a copper mine in China [7], where ground metal concentrations in the Jiangxi province in China was considered as background.

The geoaccumulation index indicates very high values for Pb in S3, S5 and S10 samples, respectively for Ni (S3 samples), Cu (S10 samples) and Zn (S10 samples).

Moderate to strong pollution from $\mathrm{Pb}$ in $\mathrm{S} 1$ and $\mathrm{S} 2$ samples, respectively from $\mathrm{Cd}$ in S10 samples was also noted.

\section{Bioavailability index}

In S1 samples itcan be observed that the bioavailability index $I_{\text {bi }}$ is very high for $\mathrm{Cd}, \mathrm{Cu}, \mathrm{Ni}$ and $\mathrm{Zn}$ (>70\%), even if the $\mathrm{pH}$ of of the soil is neutral, which implies the leaching of these metals to the vegetation and the groundwater (table 10). It should be noted that for an $I$ value of $45 \%$ for lead, due to the high pseudo-total metal content, the mobile fraction exceeds the alert threshold for sensitive uses land.

Table 9

INDEX OF GEOACCUMULATION (IGEO) IN SOIL SAMPLES

\begin{tabular}{|c|c|c|c|c|c|c|c|c|}
\hline \multirow{2}{*}{ Sample } & \multicolumn{6}{|c|}{$\mathrm{I}_{\mathrm{g} \infty}$} & \multirow[t]{2}{*}{$\mathrm{I}_{\text {g.0 }}$ class } & \multirow[t]{2}{*}{ Soil quality } \\
\hline & $\mathrm{Cd}$ & $\mathrm{Cr}$ & $\mathrm{Cu}$ & $\mathrm{Ni}$ & $\mathrm{Pb}$ & $\mathrm{Zn}$ & & \\
\hline $\mathrm{S} 1 / 1$ & 0.06 & 0.03 & 0.58 & 0.43 & 2.47 & 0.40 & $0-3$ & unpolluted to moderately to strongly \\
\hline $\mathrm{S} 1 / 2$ & -0.15 & -0.50 & 0.33 & -0.71 & 2.28 & 0.33 & $0-3$ & unpolluted to moderately to strongly \\
\hline $\mathrm{S} 2 / 1$ & 0.35 & -0.20 & 0.58 & 0.99 & 2.79 & 0.71 & $0-3$ & unpolluted to moderately to strongly \\
\hline $\mathrm{S} 2 / 2$ & 0.23 & 0.29 & -1.02 & 0.75 & 2.83 & 0.72 & $0-3$ & unpolluted to moderately to strongly \\
\hline $\mathrm{S} 3 / 1$ & 1.49 & 0.71 & 1.62 & 4.35 & 4.89 & 1.94 & $0-5$ & $\begin{array}{l}\text { unpolluted to strongly to very strong } \\
\text { polluted }\end{array}$ \\
\hline $\mathrm{S} 3 / 2$ & 1.37 & 0.47 & 1.56 & 4.24 & 4.68 & 1.80 & $0-5$ & $\begin{array}{l}\text { unpolluted to strongly to very strong } \\
\text { polluted }\end{array}$ \\
\hline S4/1 & 1.22 & -1.38 & -0.56 & -1.41 & 2.00 & 0.36 & $0-2$ & unpolluted to moderately polluted \\
\hline $\mathrm{S} 4 / 2$ & 1.55 & -1.34 & -1.01 & -1.3 & 1.87 & 0.22 & $0-2$ & unpolluted to moderately polluted \\
\hline $\mathrm{S} 5 / 1$ & -0.53 & -3.05 & -0.97 & -3.26 & 3.47 & 0.06 & $0-4$ & unpolluted to strongly polluted \\
\hline $\mathrm{S} 5 / 2$ & -1.5 & -3.32 & -1.51 & -3.77 & 3.46 & -0.57 & $0-4$ & unpolluted to strongly polluted \\
\hline $\mathrm{S} 6 / 1$ & -0.49 & -1.27 & -0.79 & -0.63 & -0.64 & -1.41 & $\leq 0$ & practically unpolluted \\
\hline $\mathrm{S} 6 / 2$ & -0.38 & -1.19 & -0.43 & -0.09 & -0.87 & -0.94 & $\leq 0$ & practically unpolluted \\
\hline $\mathrm{S} 7 / 1$ & -3.42 & -0.61 & -0.29 & 0.32 & -0.49 & -1.01 & $\leq 0$ & practically unpolluted \\
\hline $\mathrm{S} 7 / 2$ & -3.64 & 0.11 & 0.12 & 1.29 & -0.66 & -0.95 & $\leq 0$ & practically unpolluted \\
\hline $\mathrm{S} 8 / 1$ & -4.91 & -3.43 & -1.66 & -2.99 & -1.16 & -1.31 & $\leq 0$ & practically unpolluted \\
\hline $\mathrm{S} 8 / 2$ & -3.77 & -3.51 & -1.67 & -3.02 & -0.93 & -1.28 & $\leq 0$ & practically unpolluted \\
\hline $\mathrm{S} 9 / 1$ & -0.96 & -2.67 & -0.15 & -1.4 & 1.1 & 0.2 & $0-2$ & unpolluted to moderately polluted \\
\hline $\mathrm{S} 9 / 2$ & -0.75 & -2.49 & -0.1 & -1.63 & 1.17 & 0.36 & $0-2$ & unpolluted to moderately polluted \\
\hline $\mathrm{S} 10 / 1$ & 2.92 & -0.82 & 3.66 & 1.33 & 4.25 & 3.28 & $0-5$ & $\begin{array}{l}\text { unpolluted to strongly to very strong } \\
\text { polluted }\end{array}$ \\
\hline $\mathrm{S} 10 / 2$ & 2.12 & -0.78 & 3.35 & 0.93 & 3.86 & 3.59 & $0-4$ & unpolluted to strongly polluted \\
\hline $\mathrm{SM} / 1$ & -0.24 & -0.63 & 1.23 & -0.2 & 0.81 & -0.5 & $0-2$ & unpolluted to moderately polluted \\
\hline $\mathrm{SM} / 2$ & -0.33 & -0.48 & 1.2 & -0.01 & 0.7 & -0.61 & $0-2$ & unpolluted to moderately polluted \\
\hline
\end{tabular}




\begin{tabular}{|l|c|c|c|c|c|c|}
\hline Sample & $\mathrm{Cd}$ & $\mathrm{Cr}$ & $\mathrm{Cu}$ & $\mathrm{Ni}$ & $\mathrm{Pb}$ & $\mathrm{Zn}$ \\
\hline $\mathrm{S} 1 / 1$ & 84.0 & 29.2 & 85.5 & 93.5 & 43.3 & 68.7 \\
\hline $\mathrm{S} 1 / 2$ & 62.2 & 27 & 66.4 & 70.5 & 45.2 & 70.2 \\
\hline $\mathrm{S} 2 / 1$ & 51.3 & 19.6 & 22.3 & 22.8 & 15.0 & 21.3 \\
\hline $\mathrm{S} 2 / 2$ & 47.2 & 15.8 & 49.9 & 30.0 & 5.10 & 10.6 \\
\hline $\mathrm{S} 3 / 1$ & 61.8 & 22.4 & 29.2 & 29.5 & 14.3 & 32.0 \\
\hline $\mathrm{S} 3 / 2$ & 54.0 & 16.6 & 26.5 & 23.5 & 15.3 & 29.8 \\
\hline $\mathrm{S} 4 / 1$ & 35.0 & 13.4 & 60.3 & 58.3 & 21.4 & 52.3 \\
\hline $\mathrm{S} 4 / 2$ & 38.4 & 7.20 & 45.7 & 48.2 & 18.9 & 51.0 \\
\hline $\mathrm{S} 5 / 1$ & 22.1 & 19.3 & 14.1 & 28.1 & 8.70 & 24.8 \\
\hline $\mathrm{S} 5 / 2$ & 18.9 & 1.80 & 17.8 & 28.2 & 17.0 & 38.3 \\
\hline $\mathrm{S} 6 / 1$ & 45.8 & 39.6 & 63.0 & 76.8 & 49.9 & 56.5 \\
\hline $\mathrm{S} 6 / 2$ & 54.8 & 40.8 & 49.6 & 29.0 & 59.8 & 52.8 \\
\hline $\mathrm{S} 7 / 1$ & 42.9 & 23.7 & 70.2 & 71.9 & 47.7 & 59.8 \\
\hline $\mathrm{S} 7 / 2$ & 41.7 & 15.9 & 42.5 & 76.6 & 26.4 & 39.0 \\
\hline $\mathrm{S} 8 / 1$ & 25.1 & 25.4 & 24.3 & 33.9 & 28.7 & 79.6 \\
\hline $\mathrm{S} 8 / 2$ & 45.5 & 24.8 & 20.0 & 24.1 & 16.9 & 64.1 \\
\hline $\mathrm{S} 9 / 1$ & 6.50 & 17.9 & 54.2 & 42.7 & 24.2 & 57.3 \\
\hline $\mathrm{S} 9 / 2$ & 7.90 & 12.7 & 45.5 & 27.6 & 17.0 & 41.7 \\
\hline $\mathrm{S} 10 / 1$ & 71.6 & 18.6 & 69.8 & 42.1 & 33.7 & 59.4 \\
\hline $\mathrm{S} 10 / 2$ & 57.0 & 27.8 & 77.4 & 21.3 & 37.9 & 70.8 \\
\hline
\end{tabular}

Table 10

BIOAVAILABILITY INDEXES ACCORDING TO METHOD I $\left(I_{\text {bio }}\right)$
The other metal contents in the mobile form fall around the normal soil value, except for lead.

In the case of $\mathrm{S} 2$ acid $p \mathrm{H}$ samples $(\mathrm{pH}=4)$, it can be noted that although the $\mathrm{Pb}$ values exceed the intervention threshold, the mobile content $\left(I_{\text {bio }}=5 \div 15 \%\right)$ is low, standing around the normal value. The other metals in the mobile form do not exceed the concentrations of the normal values in the soil. Regarding S3 samples, which are highly polluted and show a $\mathrm{pH}$ in the acid range $(\mathrm{pH}=$ 3.6), the mobile fraction is above the intervention threshold for $\mathrm{Pb}$ and $\mathrm{Ni}$ even if $I_{\text {in }}$ is in the $15 \div 30 \%$ range. $\mathrm{Cd}$ is bioavailable in a percentage of $60 \%$, but the obtained values are below the alert threshold.

In the case of $\mathrm{S} 4$ samples ( $p \mathrm{H}=5.7)$, the total metal contents are either low $(\mathrm{Cr}, \mathrm{Cu}, \mathrm{Ni}$ and $\mathrm{Zn})$ or the bioavailability percentage is low ( $\mathrm{Pb}, \mathrm{Cd}$ ) which makes the mobile fraction values to fall in the normal range concentration.

For the $\mathrm{S} 5$ samples ( $p \mathrm{H}=3.6$ ), low percentages of bioavailability $(2 \div 38 \%)$ are recorded, so that all mobile values (except for $\mathrm{Pb}$ in the depth layer where the alert threshold is exceeded) are lower than normal values. The S6 samples (neutral $p H$ ) show very high bioavailability $(30 \%$ $\div 77 \%$ ), but low metal content in pseudo-total concentration leads to mobile contents below normal levels.

A similar situation with $\mathrm{S} 6$ occurs in $\mathrm{S7}, \mathrm{S} 8$ and $\mathrm{S9}$ samples, buthaving the $\mathrm{pH}$ in the acid range (S7, $\mathrm{pH}=3.7$; S8, $p H=5.5$ and $p H=5.2$ in S9).

In the case of S10 samples, although the $\mathrm{pH}$ is neutral, because of the high metal content and also because of the bioavailability rates falling in the $22 \div 77 \%$ range, the $\mathrm{Cd}$ (first depth), $\mathrm{Cu}, \mathrm{Pb}$ and $\mathrm{Zn}$ mobile metals are above the intervention threshold value, posing a danger to both vegetation and groundwater and surface water pollution.

Metal values in the mobile fraction for the control sample ( $p \mathrm{H}=4.8$ ) are below or around the normal value.

As mentioned in our previous study [12], which investigated the quality of early spring collected vegetation in the Certej area, significant amounts of $\mathrm{Cd}, \mathrm{Ni}, \mathrm{Pb}$ and $\mathrm{Zn}$ were detected in the vegetation samples. Thus, both leaves and roots have accumulated levels above normal values for $\mathrm{Ni}$ ( $70 \%$ of the collected samples), correlated with either elevated $I_{\text {bio }}$ indices or acidic $\mathrm{pH}$. A low percentage of $19 \%$ of vegetation samples [12] showed $\mathrm{Pb}$ values above the maximum limitallowed, despite the very high lead content in the soil, but correlated with the relative low mobility of this metal. There was an accumulation over time of $\mathrm{Pb}$ content in the bark of some trees (Carpinus betulus).

With regard to the $\mathrm{Cr}$ and $\mathrm{Cu}$ content, in all 36 collected samples of vegetation, they fall into the normal concentration range, either due to their low pseudo-total content $(\mathrm{Cr}, \mathrm{Cu})$ or because of their low mobility $(\mathrm{Cu})$.

A low percentage of $11 \%$ of vegetation samples contain $\mathrm{Cd}$ above the maximum admissible level in both leaves and bark (Carpinus betulus). In terms of zinc content, $25 \%$ of the vegetation samples contain $\mathrm{Zn}$ above the admissible content, found in the root, bark, leaves. The highest concentrations are found in the vegetation samples collected at points S3 and S10, correlated with both high zinc content and high percentage of $I_{\text {bio }}$

\section{Conclusions}

The study in the Certej mining area, which aimed to characterize the soil quality, complements the previous studies undertaken in this area where the quality of vegetation, surface water and sediment was investigated. Thus, it creates an overview of the decommissioned and heavily polluted mining area, establishing correlations between the environmental factors.

The $\mathrm{mC}_{\mathrm{f}}, \mathrm{EF}, \mathrm{I}$ pollution indexes evaluated based on the pseudo-total metal content provide only partial information on the environmental pollution potential, a bioavailability study of the metal in the soil being necessary.

Thus, three single chemical extraction methods were tested, selecting the method using EDTA and $\mathrm{CH}_{3} \mathrm{COONH}_{4}$ as the optimal method for mobility assessment. 
The study highlighted the transfer of metals from the soil to the vegetation, as metal content was found in all the analyzed vegetation types (root, leaf, bark, stem).

Acknowledgements. The authors acknowledge the financial support offered by The National Research Program Nucleu, through MEDIND Project, Agreement no. 13N/2014, Project code PN 09130219.

\section{References}

1. STANESCU, B., KIM, L., LEHR, C., STANESCU, E., $20^{\text {th }}$ International Symposium The Environment and the Industry, 2017, p.134.

2. BRALLIER, S., HARRISON, R.B., HENRY, C,L., DONGSEN, X., Water Air Soil Pollut., 86, no.1-4, 1996. p. 195.

3. CHUAN, M., SHU, G., LIU, J., Water Air Soil Pollut., 90, no.3-4, 1996, p. 543.

4. YANG, W., LI, X., PEI, J., SUN, T., SHAO, D., BAI, J., LI, Y., Chemosphere, 189, 2017, p.661.

5. PETRESCU, M., BUCUR, E., DIODIU, R., BRATU, M., SERBANESCU, A., BARBU, M., $20^{\text {th }}$ International Symposium The Environment and the Industry, 2017, p.134.

6. COELHO, C., FORET, C., BAZIN, C., LEDUC, L., HAMMADA, M., INACIO, M., BEDELL, J.P., Sci. Total Environ., 635, 2018, p.1317.

7. ZHIYUAN, W., DENGFENG, W., HUIPING, Z., ZHIPING, Q., Procedia Environ. Sci., 10, 2011, p.1946.

8. ABBASI, A.M., IQBAL, J., KHAN, M. A., SHAH, M. H., Ecotoxicol. Environ. Saf., 92, 2013, p.237.

9. HASAN, M., KAUSAR, D., AKHTER, G., SHAH, M., Ecotoxicol. Environ. Saf., 147, 2018, p.283.

10. SWARNALATHA, K., LETHA, J., AYOOB, S., J. Urban Environ. Engng, 7, no.2, 2013, p. 323.
11. KIM, L., VASILE, G.G., STANESCU, B., DINU, C., ENE, C., Rev. Chim.(Bucharest), 67, no.8, 2016, p.1441.

12. DINU, C., UNGUREANU, E.M., VASILE, G.G, KIM, L., IONESCU, I., ENE, C., SIMION, M., Rev. Chim.(Bucharest), 69, no.1, 2018, p.14. 13. *** ISO 1038-5:2005- Soil quality. Sampling. Part 5: Guidance on the procedure for the investigation of urban and industrial sites with regard to soil contamination

14. *** ISO 11464/2006 Soil quality - Pretreatment of samples for physical - chemical analysis. 2006

15. PEIJ NENBURG, W.J .G.M., ZABLOTSKAJA, M., VIJVER, G., Ecotoxicol. Environ. Saf., 67, 2007, p.163.

16.*** NF X31-120:2003. Qualite des sols - Determination du cuivre, du fer, du manganese et du zinc - Extraction par l'acetate d'ammonium en présence d'EDTA, Association Francaise de Normalisation.

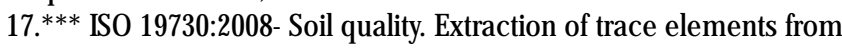
soil using ammonium

nitrate solution

18.*** ONORM L 1094-2:2016 - Chemical analyses of soils - Extraction of trace elements with salt

solutions - Part 2: Extraction with ammonium acetate solution

19. LOSKA, K., WIECHULA, D., BARSKA, B., CEBULA, E., CHOJ NECKA, A., Pol. J. Environ. Stud., 12, no.2, 2003, p.187.

20. LIDE, D.R., Handbook of Chemistry and Physics, Internet Version 2005, 85 ${ }^{\text {th }}$ edition, CRC Press, Boca Raton, FL, 2005, p. 2373

21. ABRAHIM, G.M.S., PARKER, R.J., Eniron. Monit. Assess., 136, 2008, p.227.

22.NEMATI, K., BAKAR, N.K.A., ABAS, M.R., SOBHANZADEH, E., J. Hazard. Mater., 192, 2011, p.402.

23.*** ORDER 756/97, Regulations on environmental pollution assessment, Reference values for soil chemical elements.

Manuscript received: 17.08 .2018 